\title{
Human post exposure anti-rabies prophylactic assistance in the south of Brazil
}

\section{Assistência profilática anti-rábica pós-exposição humana no sul do Brasil}

\author{
Jaíne Soares de Paula Vasconcellos ${ }^{1 *}$; Fagner D'ambroso Fernandes ${ }^{2}$; \\ Fabiana Raquel Ratzlaff'; Sônia de Ávila Botton ${ }^{3}$; Fernanda Silveira Flores Vogel'; \\ Luciane Silva Ramos ${ }^{4}$; Luís Antônio Sangioni ${ }^{3}$
}

\section{Highlights}

Canine aggression notification and appropriate human anti-rabies approaches.

Human prophylactic anti-rabies treatment: Epidemiology and economic aspects for UHS.

Anti-rabies prophylaxis in association with health promotion and education actions.

\section{Abstract}

Rabies is a zoonosis caused by Lyssavirus, with progressive development and a high lethality rate. In Brazil, rabies and accidents caused by animals potentially transmitting the disease are mandatory notification injuries. Exposure to rabies infection places a high financial burden on public health systems, especially for the care of people who are exposed and have a high risk of death. We aimed to define the epidemiological profile of human rabies post-exposure assistance in the municipality of Santa Maria, Rio Grande do Sul, Brazil, from 2010 to 2015. Data from Brazil's Notifiable Diseases Information System were obtained and analyzed; these data were acquired by the completion of individual inquiry forms querying human antirabies assistance. A total of $55 \%(1,898 / 3,453)$ of anti-rabies assistance cases involved women and $45 \%$ $(1,555 / 3,453)$ men. The highest occurrence $(54.5 \%-1,882 / 3,453)$ was in the age group of $20-59$ years. Most registered cases $(87.5 \%-3,024 / 3.453)$ were caused by dogs, followed by cats $(10.9 \%-378 / 3,453)$. The lower limb $(22.1 \%-617 / 2,790)$ was the area of the body with the highest number of canine bites. We observed incorrect indications for the treatment. We suggest further training for health professionals involved in rabies post-exposure prophylaxis care, and dissemination of information aimed at educating users about the importance of animal-related injuries.

Key words: Epidemiological surveillance. Notification. Treatment. Zoonosis.

1 Doctoral Students in the Graduate Program in Veterinary Medicine, Universidade Federal de Santa Maria, UFSM, Santa Maria, RS, Brazil. E-mail: veterinariavasconcellos@gmail.com; fabiratzlaff@yahoo.com.br

2 Master's Student in the Graduate Program in Veterinary Medicine, UFSM, Santa Maria, RS, Brazil. E-mail: fagnermedvet@gmail.com

3 Profs. Drs., Department of Preventive Veterinary Medicine, UFSM, Santa Maria, RS, Brazil. E-mail: sabott20@gmail. com; fefevogel@gmail.com; lasangioni@gmail.com

${ }^{4}$ Nurse in the Epidemiological Surveillance Sector, Superintendência de Vigilância Sanitária de Santa Maria, SVS/SM, Santa Maria, RS, Brazil. E-mail: luciane_silva_ramos@yahoo.com.br

* Author for correspondence

Received: July 03, 2021 - Approved: June 14, 2021 


\section{Resumo}

A raiva é uma zoonose causada por Lyssavirus, com desenvolvimento progressivo e alta taxa de letalidade. No Brasil, a raiva e os acidentes causados por animais potencialmente transmissores da doença, são agravos de notificação obrigatória. A exposição à infecção por raiva coloca um alto ônus financeiro para o sistema público de saúde, especialmente para o atendimento de pessoas expostas e com alto risco de morte. O objetivo deste estudo foi definir o perfil epidemiológico da assistência pós-exposição à raiva humana no município de Santa Maria, Rio Grande do Sul, Brasil, de 2010 a 2015. Foram obtidos e analisados os dados do Sistema de Informações sobre Doenças Notificáveis do Brasil (SINAM); adquiridos por meio do preenchimento de formulários de consulta individuais, verificando a assistência antirrábica humana. Um total de 55\% (1.898/3.453) e 45\% (1.555/3.453) dos casos de assistência anti-rábica envolveu mulheres e homens respectivamente, com maior ocorrência na faixa etária de 20 a 59 anos (54,5\% - 1.882/3.453). A maioria dos casos registrados (87,5\% - 3.024/3.453) foi causada por cães e 10,9\% (378/3.453) por gatos. $O$ membro inferior (22,1\% - 617/2.790) foi a área do corpo com o maior número de agressões por cães. Desta forma, sugere-se o treinamento para profissionais de saúde envolvidos no tratamento profilático da raiva após a exposição e disseminação de informações destinadas a educar os usuários sobre a importância das lesões relacionadas a animais.

Palavras-chave: Vigilância epidemiológica. Notificação. Tratamento. Zoonoses.

\section{Introduction}

Rabies is a viral encephalitis that typically presents with an acute and progressive disease course. All mammals are considered sources of rabies infection and may transmit the virus to humans (Ministério da Saúde [MS], 2011). Infection occurs by the inoculation of rabies virus, usually present in the saliva and secretions of infected animals, through biting, scratching, or by licking damaged skin or mucous membranes, and through aerosols or corneal transplantation (Hankins \& Rosekrans, 2004).

In Brazil, any instance of aggression that involves biting, licking, scratching, or indirect contact with animals that are potential transmitters of rabies should be notified through the Human Anti-Rabies Treatment Sheet (HARTS) and registered with Brazil's Notifiable Diseases Information System (Sistema de Informações de Agravos de
Notificação - SINAN) (Portaria nº 1.271, 2014). Anti-rabies assistance for animal-related injury is among the three injuries with the highest number of notifications in the country, with more than 500,000 notifications registered in SINAN per year (Ministério da Saúde [MS], 2016a). A study of Wada, Rocha and MaiaElkhoury (2011) showed that the vaccination campaigns in domestic animals established by the National Program for Human Rabies Prophylaxis in 1973 provided a reduction in human and animal rabies.

In assisting people affected by possible transmitters of rabies, health professionals should perform a complete anamnesis, using the HARTS as a reference for most of the required information, aiming to determine the correct indication for rabies post-exposure prophylaxis (Ministério da Saúde [MS], 2017). Using this, physicians can establish the best treatment by considering the epidemiological issues of each case, while the veterinarians 
can take any necessary sanitary measures regarding the aggressor animal (Oliveira et al., 2012). Veterinarians may enact measures such as animal observation and/or guidance, in addition to taking actions common to professionals in the Family Health Support Centers (FHSC).

According to the Ministry of Health of Brazil (MHB), from 2011 to 2016, there were a total 3,628,549 cases of anti-rabies assistance registered, with aggressions by dogs totaling $3,001,857$ and those by cats totaling 461,385 . The Southeast Region had the highest number of notifications, with 1,433,773 cases, followed by the northeast $(998,008)$, south $(562,447)$ north $(352,497)$, and central-west $(281,824)$ regions. Studies were conducted on cases of anti-rabies assistance to establish the epidemiological aspects of this type of injury using notification sheets (Ministério da Saúde [MS], 2016b).

Several studies carried out in different parts of Brazil reported cases of rabies ranging from 47 to 132,452 cases, with the lowest occurrence observed in Santa Catarina (Müller, Seger, \& Gabiatti, 2010) and the highest occurring in Minas Gerais (Oliveira et al., 2012).

Information note \# 26-SEl / 2017-CGPNI / DEVIT / SVS / MS provides the procedure to be followed according to the severity of accidents, being classified as minor accidents that may involve animals without suspicion or suspected to be rabid, and serious accidents involving animals without suspicion or with clinical suspicion. In addition, through the Technical Advisory Committee on Immunization (CTAI), a prophylaxis scheme for human rabies of 4 to 5 post-exposure doses was adopted (MS, 2017). Both the serum and rabies vaccines used in prophylactic treatments can cause side effects. However the unnecessary use of anti-rabies immunizers can expose the patient to adverse events, as well as constitute a waste of financial resources for public health (Costa et al., 2000).

Thus, analysis of data on human antirabies assistance, as well as the adequacy of the indicated treatments according to the norms prioritized by the MHB (MS, 2017), is essential for health surveillance as well as for the adequate use of financial resources and planning of health actions. Hence, this study aimed to delineate the epidemiological profile and evaluate the prophylactic conduct related to human post-exposure anti-rabies assistance in the municipality of Santa Maria, RS.

\section{Materials and Methods}

The present study was conducted in the municipality of Santa Maria in the state of Rio Grande do Sul (RS), Brazil, located at latitude $-29^{\circ} 41^{\prime} 03^{\prime \prime} \mathrm{S}$ and longitude $-53^{\circ}$ 48 ' $25^{\prime \prime}$ W, with an area of $1,781,757 \mathrm{~km}^{2}$ and a population of 277,309 inhabitants. The municipality has the ninth highest Municipal Human Development Index and the fifth most populous in RS (Instituto Brasileiro de Geografia e Estatística [IBGE], 2016).

We conducted a descriptive study in which we analyzed 3,453 notifications of postexposure anti-rabies assistance compiled by Epidemiological Surveillance officers of the municipality, and described cases that occurred in Santa Maria from January 4, 2010, to December 31, 2015.

Data on animal-related injuries were obtained through notifications registered in the SINAN and corresponded to the inquiry sheets from the MHB. This information was previously completed manually by 
professionals in the reference health units at the time of assistance and subsequently sent to the Epidemiological Surveillance sector of the municipality for notification to SINAN.

The SINAN data were analyzed using Tabwin ${ }^{\circledR}$ software and later exported to Excel ${ }^{\circledR}$ spreadsheets. A database was created, and the data were statistically analyzed using $\mathrm{R}^{\circledR}$ software. Variables considered for characterization of the epidemiological profile of animal-related injuries were general information(date ofassistanceandmunicipality of notification), user (age, sex, educational level, and pre-exposure treatment), residence (municipality of residence), injury (injured area, type of injury, and type of exposure to the virus), aggressor animal (species, initial condition of the animal for the purpose of treatment choice, final condition and possibility of observation), and treatment (indicated treatment, treatment interruption, and reason for the discontinuation of treatment). To analyze the occurrence of animal-related injuries, age categories were established (Veloso, Aerts, Fetzer, Anjos, \& Sangiovanni, 2011a). The relative and absolute frequencies were calculated for all variables. In addition, to test the associations of interest, we used correlation coefficient calculations and chi-squared tests for association and prevalence ratios, with $95 \%$ confidence intervals (Cls) and a significance level of $\mathrm{P}<$ 0.05. Furthermore, the standard deviation of the variables of interest was calculated.

This study was approved by the ResearchEthics Committeewith Human Beings of the Universidade Federal de Santa Maria (UFSM) (registry 52608116.5.000053456) and was initiated after receiving authorization from the Permanent Education Center of the Secretary of Health of the Municipality of Santa Maria.

\section{Results and Discussion}

In 2010, 2011, 2012, 2013, 2014, and 2015 , there were $403,439,584,611,703$, and 713 registered cases of anti-rabies assistance, respectively. In 2015, there was an increase of $76.9 \%$ from the 403 cases recorded in 2010. The number of injuries increased by an average of $12.6 \%$ per year between 2010 and 2015. From 2011 to 2012, there was a $33 \%$ increase (145) in the number of cases and the highest annual sequential growth in the analyzed period.

Regarding the sex of injured people, $55 \%(1,898 / 3,453)$ of cases occurred in women and $45 \%(1,555 / 3,453)$ in men. Additionally, there were records involving children up to 1 year of age, which accounts for $2.4 \%$ $(83 / 3,453)$ of the cases, and elderly people up to 94 years of age, which accounts for $0.03 \%$ $(1 / 3,453)$ of the cases. A study conducted in Porto Alegre using the same age categories found a higher occurrence in children (up to 12 years old, 59.6\%) and adolescents (13-19 years old, 57.9\%) among men, and in elderly people (more than 60 years old, 63.4\%) among women (Veloso, Aerts, Fetzer, Anjos, \& Sangiovanni, 2011b). In the case of children (up to age 12 years), the occurrence of these injuries may be related to their greater curiosity about animals and exposure while playing, leading to a bite or scratch (Carvalho \& Silva, 2007). The higher occurrence of antirabies assistance in adults (20-59 years old) in this study may be explained by greater daily exposure among people in this age group who handle and care for domestic animals, as well as their propensity to walk on public roads (Veloso et al., 2011a).

The highest number of injuries of antirabies assistance occurred among individuals 
aged $20-59$ years $(54.5 \% ; 1,882 / 3,453)\left(\chi^{2}=\right.$ 41.06; $P=1.47 \times 10-10)$, comprising $31.3 \%$ $(1,080 / 3,453)$ of female cases and $23.2 \%$ $(802 / 3,453)$ of males (Table 1). Most registered injuries were caused by dogs and cats, accounting for $87.6 \%(3,024 / 3,453)$ and $10.9 \%$ $(378 / 3,453)$ of the total cases, respectively. The cases of anti-rabies assistance due to a dog bite that occurred in people aged between 20 and 59 years accounted for $43 \%(1,488 / 3,453)$ of cases and constituted the majority of assistance provided. The age group most affected by canine aggression was between 20 and 59 years old, with $23.5 \%(713 / 3,024)$ and $29.5 \%(894 / 3,024)$ $\left(X^{2}=20.39, P=6.33 \times 10-6\right)$ of the cases in males and females, respectively. Regarding the injury caused by cats, it was verified that women aged 20-59 years were the most affected in $43.9 \%(166 / 378, \mathrm{P}=<2.2 \times 10-16)$ of notified cases (Table 2). Rolim, Lopes and Navarro (2003) reported that the majority of occurrences of anti-rabies disorders were found in adult women. The present study also found the highest occurrence of this condition in women, which may indicate that activities related to the care of pets are often attributed to women, placing them at greater risk exposure (Veloso et al., 2011a).

Regarding the level of education of people assisted in rabies accidents, it is emphasized that this data was absent in the SINAN in 28\% $(967 / 3,453)$ of the registered cases. However, it can be seen that the highest number of injuries, $17 \%(589 / 3,453)$, occurred among people who completed high school. In the municipality of Maringá, Paraná, it was also observed that a high school educational level was most frequent among people who experienced animal-related injuries (Correa, Martins, Chagas, \& Ferreira, 2014). These findings are similar to those obtained in this study.

\section{Table 1}

Number of post exposure anti-rabies assistances distributed by gender, according to the age group, occurred in the period between 2010 and 2015, Santa Maria, RS, Brazil.

\begin{tabular}{|ccccc|}
\hline Age group & \multicolumn{2}{c}{ Number of injuries per gender } & Standard Deviation & P-value \\
\hline Up to 12 years old & 398 & 278 & 84.85 & $3.92 \times 10^{-6}$ \\
\hline $13-19$ & 144 & 148 & 2.83 & 0.8149 \\
\hline $20-59$ & 802 & 1080 & 196.58 & $1.47 \times 10^{-10}$ \\
\hline More than 60 years old & 211 & 392 & 127.99 & $1.69 \times 10^{-13}$ \\
\hline Total & 1555 & 1898 & & \\
\hline
\end{tabular}




\section{Table 2}

Number of anti-rabies assistances caused by canine and feline species distributed by gender, according to the age group, during the period of 2010 to 2015, Santa Maria, RS, Brazil.

\begin{tabular}{|c|cccc|}
\hline \multirow{2}{*}{ Gender } & Age group & Canine & Feline & Standard Deviation \\
\hline \multirow{3}{*}{ Masculine } & Up to 12 years old & 378 & 17 & 255.27 \\
\cline { 2 - 4 } & $13-19$ & 134 & 7 & 89.80 \\
& $20-59$ & 713 & 70 & 454.67 \\
\cline { 2 - 4 } & More than 60 years old & 179 & 29 & 106.07 \\
\cline { 2 - 4 } Feminine & Up to 12 years old & 261 & 16 & 173.24 \\
& $13-19$ & 133 & 15 & 83.44 \\
& $20-59$ & 894 & 166 & 514.77 \\
\hline & More than 60 years old & 332 & 58 & 193.75
\end{tabular}

Regarding the area of exposure of the body injured by canine bite in people aged $20-59$ years old $\left(\chi^{2}=611.03 ; P=2.2 \times 10-16\right)$, $22.1 \%(617 / 2,790)$ of cases occurred in the lower limb, while $19.7 \%(551 / 2,790)$ occurred in the hands and feet (Table 3 ). It is noteworthy that people aged 20 to 59 years old $\left(\chi^{2}=17.96\right.$; $\mathrm{P}=0.0063)$ had the most serious injuries, which accounted for $23.4 \%(809 / 3,453)$ and $16.4 \%$ $(567 / 3,453)$ of the deep injuries in women and men, respectively (Table 4). Carvalho and Silva (2007) found greater cases in the lower limbs in older age groups, which may be related to the care of the guardians with the animals. Similar to our findings, a study conducted in Minas Gerais found a higher frequency of injuries among adults involving the lower limbs, hands, and feet (Oliveira et al., 2012). We can infer that the high number of injuries involving the hands and feet can be attributed to the position of self-defense assumed by the injured person at the moment of an animal attack (Silva, Brandespim, Rocha, Leite, \& Oliveira, 2013).

\section{Table 3}

Number of post exposure anti-rabies assistances distributed by area of exposure of the body and age group of the attacked people caused by canine bite, between 2010 and 2015, Santa Maria, RS

\begin{tabular}{ccccccccc}
$\begin{array}{c}\text { Type of } \\
\text { contact }\end{array}$ & Age group & $\begin{array}{c}\text { Mucous } \\
\text { membrane }\end{array}$ & $\begin{array}{c}\text { Head/ } \\
\text { Neck }\end{array}$ & $\begin{array}{c}\text { Hands/ } \\
\text { Feet }\end{array}$ & $\begin{array}{c}\text { Torso } \\
\text { Up to 12 years old }\end{array}$ & $\begin{array}{c}\text { Upper } \\
\text { Limb }\end{array}$ & $\begin{array}{c}\text { Lower } \\
\text { Limb }\end{array}$ & $\begin{array}{c}\text { Standard } \\
\text { Deviation }\end{array}$ \\
$\begin{array}{c}\text { Canine } \\
\text { bite }\end{array}$ & $13-19$ & 207 & 99 & 41 & 55 & 151 & 71.47 \\
& $20-59$ & 3 & 12 & 73 & 13 & 32 & 114 & 43.60 \\
& More than 60 years old & 2 & 9 & 217 & 9 & 55 & 188 & 97.18 \\
\hline
\end{tabular}


Table 4

Number of post exposure anti-rabies assistances distributed by type of injury, gender and age group of the attacked people, between 2010 and 2015, Santa Maria, RS

\begin{tabular}{|c|c|c|c|c|c|c|}
\hline \multirow[b]{2}{*}{0,5} & \multirow[b]{2}{*}{ Age group } & \multicolumn{5}{|c|}{ Number of injuries per type of injury } \\
\hline & & Deep & Superficial & Dilacerating & Ignored & $\begin{array}{l}\text { Standard } \\
\text { Deviation }\end{array}$ \\
\hline \multirow{4}{*}{ Masculine } & Up to 12 years old & 310 & 80 & 8 & 0 & 144.87 \\
\hline & $13-19$ & 99 & 42 & 3 & 0 & 46.15 \\
\hline & $20-59$ & 567 & 207 & 27 & 1 & 260.94 \\
\hline & More than 60 years old & 168 & 40 & 2 & 1 & 78.95 \\
\hline \multirow{4}{*}{ Feminine } & Up to 12 years old & 213 & 59 & 6 & 0 & 99.27 \\
\hline & $13-19$ & 105 & 41 & 2 & 0 & 49.11 \\
\hline & $20-59$ & 809 & 252 & 18 & 1 & 377.14 \\
\hline & More than 60 years old & 312 & 70 & 10 & 0 & 145.98 \\
\hline
\end{tabular}

Most injuries caused by dogs are superficial (Correa et al., 2014). Deep injuries cause greater concern and make people more likely to seek assistance in the health network, which may account for the greater reported occurrence of deep type injuries. Similar to the findings of Silva et al. (2013), Correa et al. (2014) also reported that the type of injury and the affected part of the body probably reflect the spatial relationship and defense movements between the animal and victim at the moment of the incident.

It should be noted that the animals involved in cases of rabies accidents were monitored in $84.2 \%(2,908 / 3,453)$ of cases; however, $15.8 \% \quad(454 / 3,453)$ were not observed. Among theanimals observed, 13.2\% $(385 / 2,908)$ had their final state ignored. Of the 3,024 injuries caused by dogs, the animals were observable in $85.6 \%(2,590 / 3,024)$ of cases and unobservable in $2.9 \%(89 / 3,024)$; this information was missing in $11.4 \%$ $(345 / 3,024)$ of cases. There were 378 cases of injuries involving the cats. These animals were observed in $83.9 \%(317 / 378)$ of the cases; however, cats could not be observed in $4.2 \%$ $(16 / 378)$ of the cases, and there was no record of information for $12 \%$ (45/378) of the animals involved in the accidents (data not shown).

Notably, $0.1 \%(4 / 3,453)$ of the animals were initially identified as rabies carriers; however, only one (0.02\%) was confirmed by laboratory diagnosis (the other two had their final condition ignored), with the animal considered healthy at the time of the aggression showed clinical signs compatible with rabies during the observation of the animal. Filgueira, Cardoso and Ferreira (2011) inferred that in the active search, there was a deficiency in the communication between health professionals and the user, or even incorrect registration of the records, even though the final condition of part of the animals is known. In $82.8 \%(2,858 / 3,453)$ of the notifications, the animals were observable and considered healthy for the purpose of treating people. During the monitoring, these animals were diagnosed as negative for rabies, both 
clinically and in laboratory tests. In $55 \%(1,568$ / 2,858 ) of these post-exposure treatments for rabies, human treatment was indicated, including animal observation + vaccine, only vaccine, or serum + vaccine. Therefore, it may be considered that there was an excessive prescription of immunobiological agents, according to MS (2017).

Post-exposure treatments for rabies commonly used by health professionals were observation of the animal plus administration of vaccine (56.6\%; 1,954/3,453) (Table 5). Only $0.08 \%(3 / 3,453)$ of the assisted people were discharged without treatment. Vaccineonly treatment was indicated in $11.2 \%$ $(386 / 3,453)$ of cases. Anti-rabies serum used in conjunction with vaccine was indicated in $2.9 \%(103 / 3,453)$ of cases, and the treatment was interrupted in $0.6 \%(20 / 3,453)$ of events. A total of $0.9 \%(30 / 3,453)$ of cases had preexposure treatment, also known as prior vaccination.

\section{Table 5}

Distribution of the number of post exposure anti-rabies assistances occurred according to the indicated treatment and if there was interruption of the treatment of the attacked people, between the periods of 2010 and 2015, Santa Maria, RS

\begin{tabular}{cccc} 
Indicated Treatment & \multicolumn{2}{c}{ Number of injuries per Treatment interruption } \\
\cline { 2 - 4 } Not filled & Interrupted & Not interrupted & Ignored \\
Pre exposure & 0 & 2 & 4 \\
Discharge of Treatment & 4 & 0 & 3 \\
Observation of the animal (if dog or cat) & 0 & 0 & 969 \\
Observation + Vaccine & 0 & 1,622 & 88 \\
Vaccine & 244 & 254 & 14 \\
Serum + Vaccine & 118 & 79 & 4 \\
Re-Exposure Scheme & 20 & 1 & 0
\end{tabular}

In only $0.4 \%(12 / 3,453)$ of cases people had indirect contact (Table 2) through objects or utensils contaminated with the secretions of suspect animals. Nevertheless, the observation of animals with the use of the vaccine has been indicated in $41.6 \%(5 / 12)$ of these cases, the use of only the vaccine in $8.3 \%(1 / 12)$, and the use of serum plus vaccine in $25 \%(3 / 12)$ of the cases. Information about the interruption of treatment was missing in $31.4 \%(1,084 / 3,453)$ of records. However $11.2 \%(387 / 3,453)$ of the treatments were interrupted, with only $57.4 \%(1,982 / 3,453)$ of the total treatments completed. In the 387 cases in which treatment was interrupted $\left(\chi^{2}\right.$ $=604.56 ; \mathrm{P}<2.2 \times 10-16), 88.63 \%(343 / 387)$ were due to abandonment, $4.39 \%$ (17/387) were due to the indication of professionals from the health units, $1.29 \%(5 / 387)$ were because the patient was transferred to another health unit, and 5.6\% (22/387) were due to having no information regarding the reason for treatment interruption recorded in the form. 
In Brazil, between 2000 and 2009, 83\% of injuries were caused by dogs, $11 \%$ by cats, $0.7 \%$ by bats, $1 \%$ by nonhuman primates and wild dogs, $0.4 \%$ by herbivores, and $3 \%$ by other species; in $0.9 \%$ of cases, this information was unavailable (Wada et al., 2011). A study published by Vargas, Romano and MerchánHamann (2019) demonstrated that between the years 2000 and 2017, of the 188 cases notified, approximately $45.7 \%$ of injuries were caused by dogs, $3.2 \%$ by cats, $43.6 \%$ by bats, $4.8 \%$ by primates, $2 \%$ by herbibores, and $0.65 \%$ undefined. Veloso et al. (2011b), Carvalho and Silva (2007), Correa et al. (2014), and Silva et al. (2013) reported that main injuries involving anti-rabies assistance are aggression in the form of canine bites, followed by feline aggression. The most common type of virus exposure (a bite) is associated with a higher number of injuries caused by dogs. It is likely that these aggressions are caused by the increasingly close contact between humans and these animals (Silva et al., 2013). In addition, the behavior and reaction of some animals in stressful situations may contribute to these data and may account for a large number of bite attacks.

Most aggressor animals involved in injuries were observed in the present investigation. By monitoring the animal to ensure that it remains healthy during the recommended period, unnecessary prescription of treatment can be avoided, regardless of the type of injury, thereby reducing the possibility of iatrogenesis and consequent added public expense (MS, 2011).

People who may be exempted from the prophylactic scheme are those who are attacked by aggressor animals, that is, a pet living exclusively in their own household, had no contact with other unknown animals, and only goes out onto the street accompanied by its owner and does not circulate in areas with a presence of bats, or any animals from a rabies-controlled area. In cases where there is uncertainty about any of these conditions, the indicated prophylaxis scheme should be followed (MS, 2017).

When there is a high number of animals considered healthy and a low number of treatment discharges, it is possible that there are flaws in the clinical evaluation of observable aggressor animals (Filgueira et al., 2011). Emphasis should be placed on the importance of and need for evaluating the animal at the time of aggression and on questioning of the injured person during the anamnesis, to determine the most appropriate action to be taken in each case.

The indications for the use of serum and vaccines are appropriate when the accident is considered serious; that is, for injuries to the head, face, neck, hands, digital pulp, and/or sole, deep, multiple, or extensive wounds on any part of the body, contact between animal saliva and mucous membranes, skin where there are serious injuries, deep claw injuries, when the animal involved is considered rabid or is missing or dead, and when the injury is caused by a wild animal (primate, bat, fox, and others), or if the patient has no history of vaccination. However, in serious injuries caused by animals without suspected rabies and in which the animal remains healthy, the case must be closed after the observation period and the use of anti-rabies serum is not indicated (MS, 2017). In cases where the injured person has received prior vaccination, seroconversion should be confirmed via serological testing; antibody titers should be $\geq 0.5 \mathrm{IU} / \mathrm{ml}$. In these cases, two doses of vaccine are recommended: one administered 
on day 0 and the other on day 3 , with no indication for serum. If the patient does not have serological evidence of minimum postvaccination antibody levels, immunobiological treatment is recommended, considering that the vaccination schedule is incomplete. In cases of possible indirect contact with rabies virus, the only recommendation is to wash the affected area well with soap and running water (MS, 2017). In each instance, additional costs would not be incurred by the Brazilian Unified Health System (Sistema Único de Saúde, SUS). In addition, the users were not unnecessarily exposed to immunobiological agents.

Treatment should be interrupted only when indicated by health professionals who follow the case. This might be appropriate when the animal has remained healthy after 10 days of observation, regardless of the type of injury (MS, 2011). A large number of discontinued treatments due to patient abandonment may be due to some patients seeking health services only for initial treatment of the injury, which may indicate a lack of knowledge on the part of the patient regarding the severity of rabies and the importance of anti-rabies treatment (Veloso et al., 2011b). Strategies are needed to better inform the local population about animal-related injuries. Among health professionals, veterinarians play a key role in sharing such information, especially on NASF teams and support networks.

\section{Conclusions}

The greater occurrence of injuries among adult users indicates that health services, especially those responsible for healthmanagementinSantaMariamunicipality, should formulate and offer strategies for information to reach the local population.
Initiatives of family health teams (Estratégia de Saúde da Família, ESF) and the use of different types of media may be effective for the dissemination of information. We suggest that periodic training be conducted for health professionals who are involved with animalrelated injuries, emphasizing the importance of notification and especially the correct manner in which to complete notification sheets, to guarantee the quality of data reported to SINAN and to determine adequate indications for treatment. The risk of inducing iatrogenesis when treatment is erroneously indicated should also be emphasized. Moreover, many mandatory fields on the notification sheet for anti-rabies assistance are ignored or left incomplete. It is also necessary to inform and educate injured users so that information is correctly reported at the time of completing notification sheets. The HARTS does not provide a field querying the location where an incident of animal aggression occurred. This prevents georeferencing analysis of locations where animal-related injuries occur, making it difficult to track areas with greater vulnerability to this type of event. The HARTS also does not have a specific field to indicate the reason for aggression.

It is important to formulate strategies and public policies to minimize animal-related injuries, which are mainly caused by dogs. Programs for responsible animal ownership can be developed by veterinarians to ensure a healthy coexistence between animals and humans, reduction in the population of stray animals, and animal population growth control. The best way to prevent rabies infection in endemic areas such as Rio Grande do Sulis through pre-exposure vaccination, and this information should be linked with health promotion and education activities. 


\section{Acknowledgement}

The authors thank the Brazilian agencies for research support: CAPES (Financial code 001) and CNPq.

\section{References}

Carvalho, C. C., \& Silva, B. T. F. (2007). Características epidemiológicas de acidentes por mordedura de cão, atendidos em unidade básica de saúde no nordeste do Brasil. Revista Brasileira em Promoção da Saúde, 20(1), 17-21. doi: 10.4025/revcivet.v5i2.41966

Correa, M. A., Martins, N. S., Chagas, E. N., \& Ferreira, E. B. (2014). Caracterização dos casos de atendimentos antirrábicos humanos na cidade de Maringá, PR. Sigmae, 2(3), 16-24. Recuperado de https://publicacoes.unifal-mg.edu.br/ revistas/index.php/sigmae/article/ view/316/pdf_1

Costa, W. A., Ávila, C. A., Valentine, E. J. G., Reichmann, M. L. A. B., Parnachão, M. R. I., Cunha, R. S., Bolzan, V. L. (2000). Profilaxia da raiva humana (2nd ed.). (Manual Técnico do Instituto Pasteur). São Paulo: Inst Pasteur.

Filgueira, A. C., Cardoso, M. D., \& Ferreira, L. O. C. (2011). Profilaxia antirrábica humana: uma análise exploratória dos atendimentos ocorridos em Salgueiro - PE, no ano de 2007. Epidemiologia e Serviços de Saúde, 20(2), 233-244. doi: 10.5123/S1679-4974 2011000200012

Hankins, D. G., \& Rosekrans, J. A. (2004). Overview, prevention, and treatment of rabies. Mayo Clinic Proceedings, 79(5), 671-676. doi: 10.4065/79.5.671
Instituto Brasileiro de Geografia e Estatística (2016). Cidades - informações gerais. Santa Maria: IBGE. Recuperado de http://cidades.ibge.gov.br/xtras/perfil. php?codmun $=431690$

Ministério da Saúde (2011). Protocolo de tratamento da raiva humana no Brasil. Série a normas e manuais técnicos. Brasília, DF. 40 pp.

Ministério da Saúde (2016a). Perfil dos atendimentos antirrábicos humanos, Brasil, 2009-2013. Boletim Epidemiológico, 47(30). Recuperado de http://portalsaude.saude.gov.br/images/ pdf/2016/julho/29/2016-010.pdf

Ministério da Saúde (2016b). Análise da situação epidemiológica da Raiva no Brasil, no período de 2011 a 2016. Brasília. Recuperado de http://portalsaude. saude.gov.br/images/pdf/2016/maio/27/ Informe-epidemiol--gico-raiva.pdf

Ministério da Saúde (2017). Nota Informativa n'26-SEI/2017-CGPNI/DEVIT/SVS/MS. Informa sobre as alterações no esquema de vacinação da raiva humana pósexposição e dá outras orientações. Recuperado de https://vet.ufmg.br/ ARQUIVOS/FCK/file/SEI_MS\%20-\%20 0075874\%20-\%20Nota\%20Informativa. pdf

Müller, G. C., Seger, J., \& Gabiatti, L. L. (2010). Avaliação dos casos de atendimento antirrábico humano notificados no Município de São Miguel do Oeste- SC no ano de 2009. Unoesc \& Ciência- ACBS, 1(2), 95-105. Recuperado de https:// portalperiodicos.unoesc.edu.br/acbs/ article/view/576/pdf 54 
Oliveira, V. M. R., Pereira, P. L. L., Silva, J. A., Miranda, C. F. J., Rodrigues, K. O., Rodrigues, T. O., \& Moreira, E. C. (2012). Mordedura canina e atendimento antirrábico humano em Minas Gerais. Arquivo Brasileiro de Medicina Veterinária e Zootecnia, 64(4), 891-898. doi: 10.1590/ S0102-09352012000400016

Portaria $n^{\circ}$ 1.271, de 6 de junho de 2014. Define a lista nacional de notificação compulsória de doenças, agravos e eventos de saúde pública nos serviços de saúde públicos e privados em todo o território nacional, nos termos do anexo, e dá outras providências. Diário Oficial da União, Brasília, DF, 9 jun. 2014. Recuperado de https://www.jusbrasil. com.br/diarios/71540830/dou-secao-109-06-2014-pg-67/pdfView

Rolim, R. L. P., Lopes, F. M. R., \& Navarro, I. T. (2003). Aspectos da vigilância epidemiológica no município de Jacarezinho, Paraná, Brasil. Semina: Ciências Agrárias, 27(2), 271-280. doi: 10.5433/1679-0359.2006v27n2p271

Silva, G. M., Brandespim, D. F., Rocha, M. D. G., Leite, R. M. B., \& Oliveira, J. M. B. (2013). Notificações de atendimento antirrábico humano na população do município de Garanhuns, Estado de Pernambuco, Brasil, no período de 2007 a 2010. Epidemiologia e Serviço de Saúde, 22(1), 95-102. doi: $10.5123 / S 1679-49742013000100010$
Vargas, A., Romano, A. P. M., \& MerchánHamann, E. (2019). Human rabies in Brazil: a descriptive study, 2000-2017. Revista Epidemiologia e Serviços de Saúde, 28(2), 1-9. doi: 10.5123/S1679-497420190002 00001

Veloso, R. D., Aerts, D. R. G. C., Fetzer, O. L., Anjos, C. B., \& Sangiovanni, J. C. (2011a). Perfil epidemiológico do atendimento antirrábico humano em Porto Alegre, RS, Brasil. Ciência e Saúde Coletiva, 16(12), 4875-4884. doi: 10.1590/S141381232011001300036

Veloso, R. D., Aerts, D. R. G. C., Fetzer, L. O., Anjos, C. B., \& Sangiovanni, J. C. (2011b). Motivos de abandono do tratamento antirrábico humano pós-exposição em Porto Alegre (RS, Brasil). Ciência e Saúde Coletiva, 16(2), 537-546. doi: 10.1590/ S1413-81232011000200017

Wada, M. Y., Rocha, S. M., \& Maia-Elkhoury, A. N. S. (2011). Situação da raiva no Brasil, 2000 a 2009. Epidemiologia e Serviço de Saúde, 20(4), 509-518. doi: 10.5123/ S1679-49742011000400010 